\title{
Evaluation of different milking practices for optimum production performance in Sahiwal
} \section{COWS}

\author{
Naveed Aslam, Muhammad Abdullah', Muhammad Fiaz², Jalees Ahmad Bhatti', Zeeshan Muhammad Iqbal', \\ Nasrullah Bangulzai ${ }^{3}$, Chang Weon $\mathrm{Choi}^{4}$ and Ik Hwan Jo ${ }^{4^{*}}$
}

\begin{abstract}
The production performance of multiparous lactating Sahiwal cows $(n=24)$ was evaluated according to both milking frequency and method. Selected animals were randomly divided into four groups containing six animals each under a completely randomized design. Cows in groups A \& B were milked by the hand milking method three times per day, respectively. Similarly, cows in groups $C \& D$ were milked by the machine milking method two and three times per day, respectively. All animals were maintained under uniform feeding and management conditions. Dry matter intake was high in animal groups milked three times per day, and it remained unchanged between the hand and machine milking methods. Milk yield was higher $(P<0.05)$ in cows milked three times compared to those milked twice per day, and it did not differ between hand and machine milking methods. Milk fat percentage was higher $(P<0.05)$ in cows milked twice per day compared to those milked three times using both machine and hand milking methods. The percentage of total solids showed a similar pattern as the fat percentage. However, percentages of protein, lactose, and non-fat solids in milk were not significantly different $(P>0.05)$ among the treatment groups. Collectively, the results show that milking three times per day instead of twice at 8-hour intervals can enhance milk yield in Sahiwal cows using both hand and machine milking methods.
\end{abstract}

Keywords: Sahiwal cows, Machine milking, Milking frequency, Milk yield, Composition

\section{Background}

Demand for milk in Pakistan is rising due to an increasing human population and higher inclination towards consumption of milk and milk products. Milk is the largest commodity amongst dairy products, making Pakistan the $4^{\text {th }}$ largest milk-producing country in worldwide. A total of 49.5 billion $\mathrm{kg}$ of milk was produced during the 2012-13 year [1]. Major sources of milk in Pakistan are cattle and buffaloes, as the country is blessed with suitable tropical breeds of dairy cattle. Sahiwal is one such renowned tropical dairy cattle breed due to its excellent heat and tick resistance [2,3]. As such, the performance of this breed in a tropical

\footnotetext{
* Correspondence: greunld@daegu.ac.kr

${ }^{4}$ Department of Animal Resources, International Research Center for Eradication of Poverty and Hunger, Daegu University, Gyeongsan, South Korea

Full list of author information is available at the end of the article
}

environment is also better than other cattle breeds due its better resistance to tick-borne diseases [4].

Cow milking is considered to be one of the most laborious and time-consuming activities at livestock farms. Additionally, considerable cost goes into this major farm operation. As a result, machine milking was invented to improve labor efficiency due to growing costs [5]. Machine milking has been shown to have the potential to increase milk production by up to $12 \%$, reduce labor by up to $18 \%$, and improve dairy cow welfare.

Increasing milking frequency from twice to three times per day may correspondingly increase milk yield from 6 to $25 \%$ during complete lactation as well as improve udder health by reducing the somatic cell count (SCC) [6-8]. The chance of clinical mastitis has also been reported to be lower in cows milked three times or more than in those milked only twice per day [9]. Milk yield can be increased by machine milking, which has beneficial effects on udder health $[10,11]$. Moreover, milking 
three times per day has been shown to increase milk yield by up to $14 \%$ compared to milking only twice per day [12]. The literature is limited regarding the effects of milking frequency as well as machine milking on milk yield, composition, and udder health of Pakistani cattle. Therefore, this study investigated the optimal milking frequency and milking method for improved production performance in Sahiwal cows.

\section{Methods}

\section{Precinct of study}

The study was conducted at the Livestock Experiment Station Jahangirabad, Khanewal. This station is situated in south central irrigated Punjab, Pakistan. Its geographical coordinates are $30^{\circ} 18^{\prime} 0^{\prime \prime}$ North, $71^{\circ} 56^{\prime} 0^{\prime \prime}$ East. Jahangirabad town in Khanewal District is well known as the homeland of Sahiwal cows, a renowned tropical dairy cattle breed in Pakistan [2,3,13]).

\section{Experimental animals and treatment groups}

Twenty-four lactating Sahiwal cows in their $3^{\text {rd }}$ to $4^{\text {th }}$ parity after parturition with similar average bodyweight, conditions, and production performance were separated into groups A, B, C, \& D. Cow milking was carried out by the hand and machine milking methods twice or three times a day, as shown in Table 1. The animals were kept for a period of 90 days, excluding a 15-day adjustment period. The cows were also properly tagged and treated for internal and external parasites. All animals were kept in separate pens under identical conditions.

\section{Feeding of animals}

Animals were given standard diet: daily green fodder (Maize)@ 40 kg per cow, wheat straw @ 4 kg per cow, and Anmol wanda (concentrate consisting of CP 16 and 68\% TDN)@ $1.0 \mathrm{~kg}$ per 2.5 liters of milk produced by each cow. Composition of Anmol Wanda is given in Table 2. Clean premises were made available to the experimental cows, and animals had ad limitum access to fresh clean water.

\section{Milking of cows}

Cows in groups A \& B were subjected to the hand milking method, whereas cows in groups C \& D were milked using a portable milking machine. However, groups A \&
Table 2 Ingredient and nutrient composition

\begin{tabular}{lcc}
\hline S. No. & Ingredient (s) & Inclusion level (\%) \\
\hline 1 & Cotton seed Cake & 18 \\
2 & Maize gluten 30 & 15 \\
3 & Canola meal & 10 \\
4 & Maize grain broken & 14 \\
5 & Wheat Bran & 25 \\
6 & Molasses & 16 \\
7 & Minerals mixture* & 2 \\
Total & & 100 \\
CP (\%) & & 16 \\
TDN (\%) & & 68
\end{tabular}

*100 Kg minerals mixture included DCP $70.81 \mathrm{~kg}, \mathrm{NaCl} 18.91 \mathrm{~kg}, \mathrm{MgSO}_{4} 8.64$ $\mathrm{kg}, \mathrm{FeSO}_{4} 0.89 \mathrm{~kg}, \mathrm{MnSO}_{4} 0.49 \mathrm{~kg}, \mathrm{ZnSO}_{4} 0.22 \mathrm{~kg}, \mathrm{CuSO}_{4} 0.03 \mathrm{~kg}, \mathrm{KI} 8.77 \mathrm{~g}$, $\mathrm{CoCl}_{2} 0.89 \mathrm{~g}$, and $\mathrm{NaSiO}_{3} 1.50 \mathrm{~g}$.

$\mathrm{C}$ were milked twice per day at 12-hour intervals at 3:00 and 15:00 hours, whereas groups B \& D were milked three times per day at 8-hour intervals at 2:00, 10:00, and 18:00 hours. Prior to milking, the udder of each cow was thoroughly washed with moderate warm water \& dried properly. The milking machine was thoroughly washed with acid and alkali solutions in lukewarm water.

\section{Data recording and parameters}

Feed intake of each experimental animal was recorded daily. Milk yields of all cows were recorded daily using a calibrated spring balance. To screen for mastitis, a few milk were tested prior to milking. Milk samples were collected from all cows every 2 weeks for milk composition analysis. The following parameters were studied to determine the response to different treatments.

1. Dry matter intake $(\mathrm{kg})$

2. Milk yield $(\mathrm{kg})$

3. Milk protein $\%$

4. Milk fat $\%$

5. Lactose\%

6. Total solids\%

\section{Laboratory analysis}

Analyses were performed in the Food \& Nutrition and Quality Operation Labs at the University of Veterinary

Table 1 Layout of experiment

\begin{tabular}{lccc}
\hline Treatment groups & Replicates & Milking method & Frequency of daily milking \\
\hline A & 6 & Manual & Twice \\
B & 6 & Manual & Thrice \\
C & 6 & Machine & Twice \\
D & 6 & Machine & Thrice \\
\hline
\end{tabular}


Table 3 Effect of milking frequency \& method on dry matter intake and milk yield in Sahiwal cows

\begin{tabular}{lcccc}
\hline Parameters & Hand milking twice (A) & Hand milking thrice (B) & Machine milking twice (C) & Machine milking thrice (D) \\
\hline Dry matter intake (Kg/day) & $7.50 \pm 0.18^{\mathrm{b}}$ & $9.30 \pm 0.11^{\mathrm{a}}$ & $7.90 \pm 0.15^{\mathrm{b}}$ & $9.50 \pm 0.15^{\mathrm{a}}$ \\
Milk yield (Kg) & $9.08 \pm 0.15^{\mathrm{b}}$ & $11.50 \pm 0.18^{\mathrm{a}}$ & $9.25 \pm 0.21^{\mathrm{b}}$ & $11.75 \pm 0.28^{\mathrm{a}}$ \\
\hline
\end{tabular}

Different superscripts in same row differ significantly $(P<0.05)$.

and Animal Sciences (UVAS), Lahore. Dry matter content of feed samples was determined according to the procedures of [14]). Milk composition analysis was carried out using a Lactoscan-S Milk Analyzer (50 W, Milkotronic Ltd., Bulgaria) in WTO-Quality Operation Labs at the UVAS, Lahore for the following milk constituents: milk fat, non-fat solids, milk protein, lactose, and total solids.

\section{Statistical analysis}

Data were analyzed using ANOVA techniques [15] under a Completely Randomized Design (CRD) using SAS 9.1.3 portable software. Differences among treatment means were tested by DMRt. The mathematical model was:

$$
\mathbf{Y i j}=\boldsymbol{\mu}+\mathbf{t i}+\mathbf{\varepsilon i j}
$$

where

Yij = each observation on $\mathbf{i}^{\text {th }}$ treatment due to $\mathbf{j}^{\text {th }}$ animal.

$\boldsymbol{\mu}=$ overall mean.

$\mathbf{\tau} \mathbf{i}=$ effect of $\mathbf{i}^{\text {th }}$ treatment $(\Sigma \mathrm{i}=0$ and $\mathrm{i}=1,2,3,4)$.

$\boldsymbol{\varepsilon} \mathrm{ij}=$ random error associated with $\mathbf{i}^{\text {th }}$ treatment and $\mathbf{j}^{\text {th }}$ animal with the restriction that variance $\sigma_{2}$ and mean zero.

\section{Results and discussion Dry Matter Intake}

Dry matter intake (DMI) in cows is shown in Table 3. Cows milked three times daily showed higher DMI compared to those milked twice per day. However, DMI was not significantly different between hand and machine milking methods. The higher DMI consumption of cows milked three times per day can be attributed to higher milk yield, which increases nutrient demands. In support of the current results, [16] previously studied the effects of milking frequency on production efficiency in Holstein cows and found that milking three times daily increased milk yield and DMI. In another study, [17] asserted that DMI increases $(\mathrm{p}<0.05)$ with greater milking frequency. The current results are also supported by previous works $([16,18,19])$ in which increased DMI was shown to be accompanied by higher milk yield due to greater milking frequency. Milk yield is an indicator of feeding behavior as increased milk yield is positively correlated with DMI [20].

\section{Milk yield}

Average daily milk yields are presented in Table 3. Milk yield was higher $(\mathrm{P}<0.05)$ in cows milked three times daily compared to cows milked twice. Milk production between the machine and hand milking treatment groups was not significantly different $(P>0.05)$. However, higher milking frequency significantly $(\mathrm{P}<0.05)$ enhanced milk yield.

Our observation of an association between enhanced milking frequency and greater milk yield has been substantiated by the literature. In a previous study, [7] reported that milk yield increased by up to $10.4 \%$ in cows milked three times per day compared to those milked twice per day. Similarly, [21] showed that milking three times daily increased milk yield in cows by up to $18 \%$. In another study, [22] showed that the yield of energy corrected milk was higher in cows milked three times per day compared to those milked twice per day.

Similarly, [23] affirmed that milking three times per day rather than twice increased milk yield in crossbred (different blood ratios among Friesian, Hariana, Brown Swiss, and Jersey breeds) cows, but at the cost of their body condition. The higher milk yield in cows milked three times per day might be due to the fact that milk

Table 4 Effects of milking frequency \& method on milk composition in Sahiwal cows

\begin{tabular}{lcccc}
\hline Parameters & Hand milking twice (A) & Hand milking thrice (B) & Machine milking twice (C) & Machine milking thrice (D) \\
\hline Protein\% & $3.35 \pm 0.06$ & $3.25 \pm 0.06$ & $3.35 \pm 0.06$ & $3.22 \pm 0.08$ \\
Fat\% & $3.68 \pm 0.04^{\mathrm{a}}$ & $3.45 \pm 0.03^{\mathrm{b}}$ & $3.70 \pm 0.04^{\mathrm{a}}$ & $3.50 \pm 0.04^{\mathrm{b}}$ \\
Lactose\% & $4.82 \pm 0.06$ & $4.87 \pm 0.02$ & $4.90 \pm 0.04$ & $4.92 \pm 0.02$ \\
Total Solids\% & $12.7 \pm 0.04^{\mathrm{a}}$ & $12.4 \pm 0.04^{\mathrm{b}}$ & $12.7 \pm 0.04^{\mathrm{a}}$ & $12.4 \pm 0.04^{\mathrm{b}}$ \\
\hline
\end{tabular}

Different superscripts in same row differ significantly $(P<0.05)$. 
secretion is a continuous process resulting in gradual elevation of internal udder pressure. Thus, more frequent milking might reduce internal udder pressure and consequently stimulate milk-secreting cells to operate at full capacity for a longer time.

\section{Milk composition}

The impacts of milking frequency and method on milk composition in Sahiwal cows are shown in Table 4. Milk fat percentage was higher $(\mathrm{P}<0.05)$ in cows milked twice compared to those milked three times per day. However, milking method did not influence fat percentage in milk. Similarly, the percentage of total solids was higher in milk from cows milked twice per day compared to those milked three times.

However, the percentages of protein and lactose in milk were not significantly different $(P>0.05)$ among cows in the different treatment groups. Milk fat content has been shown to be affected by milking frequency $[7,24,25])$. Similarly, cows milked three times per day produce milk with a lower fat content compared to those milked once a day during early lactation [26]. The negative effect of frequent milking on fat content can be attributed to increased air exposure due to frequent milking, enzymatic activity of fatty acid syntethase, and increased production of short-chain fatty acids [7]. Another factor might be the shortened time for fat synthesis in the case of 8-hour intervals. The high percentage of total solids in milk from cows milked twice daily might be due to a high fat percentage.

\section{Conclusion}

It can be concluded that milking three times instead of only twice per day at 8-hour intervals can enhance milk yield in Sahiwal cows using both hand and machine milking methods.

\section{Competing interests \\ The authors declare that they have no competing interests.}

\section{Authors' contributions}

NA, MA, MF, CWC and IHJ participated in the design of the study and the performance of the entire experiment. ZMI made the laboratory work and data interpretation. NB and JAB performed the statistical analysis and preparing the manuscript. All authors helped to draft the manuscript, and they read and approved the final manuscript.

\section{Acknowledgements}

This work was supported by the Directorate of Research Centre for Conservation of Sahiwal Cattle, Livestock \& Dairy Development Department, Government of Punjab, Pakistan as well as the Cooperative Research Program for Agriculture Science \& Technology Development (PJ009289042014), Rural Development Administration, Republic of Korea.

\footnotetext{
Author details

${ }^{1}$ Department of Livestock Production, Faculty of Animal Production and Technology, University of Veterinary and Animal Sciences, Lahore, Pakistan. ${ }^{2}$ Department of Livestock Production and Management, Pir Mehr Ali Shah Arid Agriculture University Murree Road Shamsabad, Rawalpindi, Pakistan. ${ }^{3}$ Department of Livestock Management, Lasbela University of Agriculture,
}

Water and Marine Sciences Balochistan, Karachi, Pakistan. ${ }^{4}$ Department of Animal Resources, International Research Center for Eradication of Poverty and Hunger, Daegu University, Gyeongsan, South Korea.

Received: 28 July 2014 Accepted: 28 July 2014

Published: 7 August 2014

\section{References}

1. GOP (Government of Pakistan): Economic Survey of Pakistan. Islamabad, Pakistan: Government of Pakistan, ministry of finance, Published by Economic Adviser Wing 2012-13.

2. Khan MS, Rehman Z, Khan MA, Ahmad S: Genetic resources and diversity in Pakistani cattle. Pakistan Vet J 2008, 28:95-102.

3. Rehman Z, Khan MS, Bhatti SA, lqbal J, lqbal A: Factors affecting first lactation performance of Sahiwal cattle in Pakistan. Arch Anim Breed 2008, 51. In press.

4. Glass EJ, Preston PM, Springbett A, Craigmile S, Kirvar E, Wilkie G, Brown CGD: Bos taurus and Bos indicus (Sahiwal) calves respond differently to infection with Theileria annulata and produce markedly different levels of acute phase proteins. Int J Parasit 2005, 35:337-347.

5. Lind O, Ipema AH, de Koning C, Mottram TT, Hermann HJ: Automatic Milking. Brussels, Belgium: International Dairy Federation; 2000. Bulletin 348/ 2000, 1-14.

6. Erdman RA, Varner M: Fixed yield responses to increased milking frequency. J Dairy Sci 1995, 78(5):1199-1203.

7. Klei LR, Lynch JM, Barbano DM, Oltenacu PA, Lednor AJ, Bandler DK: Influence of milking three times a day on milk quality. J Dairy Sci 1997, 80:427-436.

8. Vorst YVD, Hogeveen H: Automatic Milking Systems and Milk Quality in the Netherlands. In Proc. Int. Symp. Robotic Milking. Edited by Hogeveen H, Meijering A. Lelystad, the Netherlands: Wageningen Pers; 2000:73-82.

9. Hillerton JE: The Effects of Milking Frequency on Mastitis. In Proceedings of the British Mastitis Conference, Stoneleigh, UK. : 1991:61-69.

10. Hillerton JE, Winter A: The Effects of Frequent Milking on Udder Physiology and Health. In Prospects for Automatic Milking. Edited by Ipema AH, Lippus AC, Metz JHM, Rossing W. Wageningen, the Netherlands: Pudoc Scientific Publishers; 1992:201-212.

11. Paape MJ, Capuco AV, Lefcourt A, Burvenich C, Miller RH: Physiological Response of Dairy Cows to Milking, Proc. Int. Symp. Prospects for Auto. Milking. Wageningen, The Netherlands: Pudoc Scientific Publishers; 1992.

12. Ipema $\mathrm{AH}$, Benders $\mathrm{E}$ : Production, duration of machine-milking and teat quality of dairy cows milked 2, 3 or 4 times daily with variable intervals. In Proc. Int. Symp. Prospects For Automatic Milking. Edited by Ipema AH, Lippus AC, Metz JHM, Rossing W. Pudoc Scientific Publishers, Wageningen, The Netherlands: Pudoc Scientific Publishers; 1992:244-252.

13. Fiaz M, Abdullah M, Pasha TN, Jabbar MA, Babar ME, Bhatti JA, Nasir M: Evaluating varying dietary energy levels for optimum growth and early puberty in Sahiwal heifers. Pakistan J Zool 2012, 44:625-634.

14. AOAC (Association of Official Analytical Chemists): Official Methods of Analysis. 17th edition. Arlington, Virginia, USA: Association of Analytical Chemists; 2000.

15. Steel RGD, Torrie JH, Dickie AD: Principles and Procedures of Statics a Biometric Approach. 3rd edition. Tronto: McGraw-Hill Publishing Company; 1997.

16. Barnes MA, Pearson RE, Lukes-Wilson AJ: Effects of milking frequency and selection for milk yield on productive efficiency of Holstein Cows. $J$ Dairy Sci 1990, 73(6):1603-1611.

17. Williams TJ, Osinowo OA, Smith OF, James IJ, Ikeobi CON, Onagbesan OM, Shittu O०, Solola FT: Effects of milking frequency on milk yield, dry matter intake and efficiency of feed utilization in wad goats. Archivos de Zootecnia 2012, 61:457-465. No. 235.

18. Bar-Pelled U, Maltz E, Bruckental I, Folman Y, Kali Y, Gacitua H, Lehrer AR, Knight $\mathrm{CH}$, Robinson $\mathrm{B}$, Voet $\mathrm{H}$, Tagari $\mathrm{H}$ : Relationship between frequent milking or suckling in early lactation and milk production of high producing dairy cows. J Dairy Sci 1995, 78(12):2726-2736.

19. Royle C, Gamsworth PC, McArthur AJ, Mepham TB: Effect of Frequent Milking on Heart Rate and Other Physiological Variables in Dairy Cows, In: Int. Symp. Prospects for Automatic Milking, Hrdoc. Wageningen. The Netherlands; 1992:237.

20. Dado RG, Allen MS: Variation in relationships among feeding, chewing and drinking variables for lactating dairy cows. J Dairy Sci 1994, 77:132. 
21. Stelwagen $\mathrm{K}$ : Effect of milking frequency on mammary functioning and shape of the lactation curve. J Dairy Sci 2001, 84(supple):E204-E211.

22. Osterman S, Bertilsson J: Extended calving interval in combination with milking two or three times per day: effects on milk production and milk composition. Livest Prod Sci 2003, 82(2-3):139-149.

23. Sirohi AS, Pandey HN, Singla M: Effects of milking frequency on feed intake, body weight and haemato-biochemical changes in crossbred cows. J Appl Anim Res 2012, 40(1):63-68.

24. O'Brien B, Ryan G, Meaney WJ, McDonagh D, Kelly A: Effect of frequency of milking on yield, composition and processing quality of milk. J Dairy Res 2002, 69(3):367-374.

25. Friggens NC, Rasmussen MD: Milk quality assessment in automatic milking systems: accounting for the effects of variable interval between milkings on milk composition system. Livest Prod Sci 2001, 73:45-54.

26. Patton J, Kenny DA, Mee JF, O'Mara FP, Wathes DC, Cook M, Murphy JJ: Effect of milking frequency and diet on milk production, energy balance, and reproduction in dairy cows. J Dairy Sci 2006, 89(5):1478-1487.

doi:10.1186/2055-0391-56-13

Cite this article as: Aslam et al: Evaluation of different milking practices for optimum production performance in Sahiwal cows. Journal of Animal Science and Technology 2014 56:13.

\section{Submit your next manuscript to BioMed Central and take full advantage of:}

- Convenient online submission

- Thorough peer review

- No space constraints or color figure charges

- Immediate publication on acceptance

- Inclusion in PubMed, CAS, Scopus and Google Scholar

- Research which is freely available for redistribution 